\title{
IONIC MASS TRANSFER IN THE ELECTROLYSIS OF FLOWING SOLUTIONS. THE ELECTRODEPOSITION OF COPPER UNDER MASS-TRANSFER CONTROL ON TUBULAR ELECTRODES.*
}

\author{
J. C. BazÁn and A. J. Arvía \\ Instituto Superior de Investigaciones, Facultad de Química y Farmacia and \\ División Ingeniería Química, Facultad de Ciencias Fisicomatemáticas, \\ Universidad Nacional de La Plata, La Plata, Argentina
}

\begin{abstract}
Ionic mass transfer for the electrodeposition of copper from aqueous copper sulphatesulphuric acid solutions has been studied on tubular stainless steel electrodes.

The following parameters were varied: rate of flow, copper ion concentration, viscosity, height and diameter of tubular electrodes, and temperature. The clata can be correlated by the dimensionless equation
\end{abstract}

$$
S h=0.647 \operatorname{Re}^{1 / 2} S c^{1 / 3} .
$$

The temperature coefficient of the kinetic mass-transfer constant is $1 \cdot 2$, corresponding to an experimental heat of activation of $3850 \pm 200 \mathrm{cal} / \mathrm{mol}$.

The solution of the momentum- and heat-transfer equations worked out by Eckert for flat plates, according to von Kármán's treatment, and recently extended by Wranglén to the analogous masstransfer problem, can be applied under certain conditions to tubular electrodes.

Résumé-On a étudiẻ le transfert ionique de masse dans l'électrodeposition des ions cuivre (II) sur des électrodes tubulaire d'acier inoxydable.

Les données expérimenteles furent obtenues en fonction des paramétres suivants: vitessede circulation de l'électrolyte, concentration d'ions cuivre, viscosité de la solution, hauteur et diamètre des électrodes et température.

On a obtenu l'equation suivante:

$$
S h=0,647 \operatorname{Re}^{1 / 2} S c^{1 / 3}
$$

Les solutions des équations obtenues par Eckert pour le transfert de chaleur et de quantité de mouvement dans le cas de plaques planes en utilisant la méthode de von Kármán, et qui ont été aussi appliquées à des problèmes analogues de transfert de masse par Wranglén, sont applicables à des électrodes tubulaire sous certaines conditions.

Zusammenfassung---Es wurde die Stofftransportgeschwindigkeit bei der elektrolytischen abscheidung von Kupfer aus wässerigen schwelfsauren Kupfersulfat-Lösungen an röhrenförmigen Elektroden aus rostfrciem Stahl untersucht.

Es wurden die folgenden Parameter variiert: die Strömungsgeschwindigkeit, die Konzentration der Kupferionen, die Zähigkeit, die Höhe und der Durchmesser der röhrenförmigen Flektroden sowie die Temperatur. Die Messwerte können durch die dimensionslose Gleichung dargestellt werden:

$$
S h=0,647 R e^{1 / 2} S c^{1 / 8} .
$$

Der Temperaturkoeffizient der Stoffübergangszahl entspricht einer Aktivierungswärme von $3850 \pm 200 \mathrm{cal} / \mathrm{mol}$.

Die Gleichung kann unter gewissen Bedingungen theoretisch abgeleitet werden, indem man die von Fckert für das Wärmeübergangsproblem und von Wranglén für das Stoffübergangsproblem an ebenen Platten ausgearbcitete Lösung, unter Anwendung der von Kármán'schen Näherung für die Impuls- und Stofftransportgleichung, auf die röhrenförmige Zelle ausdehnt.

\section{INTRODUCTION}

IONIC mass-transfer processes under forced convection with laminar flow have been studied in several cases. The greatest attention has been paid to the rotating disk

* Manuscript received 1 May 1963 
electrode, the theory of which was developed several years ago by Levich. ${ }^{1}$ The streaming mercury electrode has also been considered in some detail by Rius, Llopis and Polo. ${ }^{2}$ Lévêque ${ }^{3}$ has also devised a streaming electrode intended for polarography and has obtained its kinetic equation. The three electrodes mentioned above are particularly interesting because the steady state forced convection is obtained by stirring the solution with the electrodes, keeping a laminar flow on their surface.

The case in which the electrodes are fixed and the electrolytic solution is streaming along the electrode surface under laminar flow has not received much attention. Lin, Denton, Gaskill and Putnam ${ }^{4}$ have studied various electrochemical reactions involving mass transfer in the inner electrode surface of a concentric cell in order to obtain design information. In recent years Jordan and Javick ${ }^{5,7}$ have considered a conical electrode placed into the stream of a flowing solution which has been successfully applied to voltammetry. Wranglén ${ }^{6}$ has published results for metal deposition on a horizontal flat plate that is simultaneously an electrode and a wall of the electrolysis cell.

We are investigating electrolytic reactions in flowing solutions employing different types of electrodes and flowing conditions. We have been studying tubular electrodes for two main purposes. First, it may be assumed that reproducible velocity and concentration profiles would result on the electrodes under certain flowing rates, and it would be useful to compare the mathematical solutions of momentum and heat transfer equations worked out for the horizontal flat plate to the tubular electrode. Secondly, if the equation for mass transfer is simple and experimental errors involved are low, it would be interesting to apply tubular cells with flowing electrolytes to hydrodynamic voltammetry studies. Therefore, if these cells are properly designed, they could be particularly useful for the kinetic study of electrochemical reactions. The mass-transfer equations obtained in the present work support these ideas, which are now under development.

\section{EXPERIMENTAL}

\section{The tubular electrolysis cell and the flowing solutions}

The electrolysis cell, Fig. 1, was made of a metal tube of which inner side was the workingelectrode. It was vertically mounted between two Pyrex glass tubes. The inside diameters of the three pieces were $1.70 \mathrm{~cm}$. The end of the tubular pieces had been perfectly polished to give very good contact between them, eliminating any binding material which could have modified the actual diameter of the cell and altered the flowing conditions into the cell. The three pieces were held together by pressing one against the other with special holders. Polyethylene tubing was useful to keep the cell in position. Tubular electrodes were made of stainless steel; four of them were employed having the following heights:

$\begin{array}{ccc}\text { electrode } & \begin{array}{c}\text { height } \\ \mathrm{cm}\end{array} & \begin{array}{c}\text { area } \\ \mathrm{cm}^{2}\end{array} \\ 1 & 6.00 & 32.0 \\ 2 & 3.00 & 16.0 \\ 3 & 1.50 & 8.00 \\ 4 & 0.75 & 4.00\end{array}$

The counter electrode was the outer surface of a copper tube of much smaller diameter, $0.47 \mathrm{~cm}$, placed at the axis of the cell. The reference electrode was placed in a special container and connected to the cell just above the working electrode, with a standard tapered joint. The potential of the working electrode was determined in three different positions as indicated in the figure. Solutions of 0.008 to $0.223 \mathrm{M} \mathrm{CuSO}_{4}$ in $\mathrm{ca} 1.5 \mathrm{M} \mathrm{H}_{2} \mathrm{SO}_{4}$ were employed. To increase the viscosity and density of the solutions glycerine was added in son experiments. The solutions were continuously pumped through the cell from bottom to top by means of a rotating pump which had a stainless steel propeller and a Lucite body. The propeller was rotated by a 1/8 H.P. a.c. motor whose rate was conveniently 


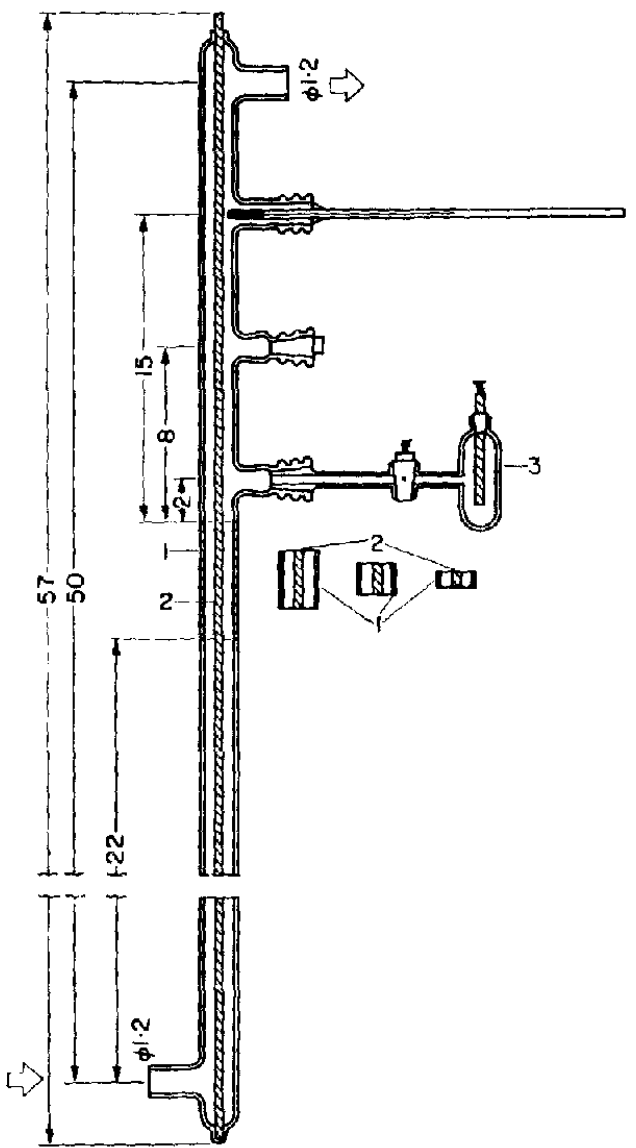

Fig. 1. Scheme of the tubular cell. 1 and 2: electrodes; 3: reference electrode; dimensions are in $\mathrm{cm}$.

adjusted to get a constant solution flow. The propeller was adjusted in the body of the pump by means of Teflon gaskets and 0 -rings to eliminate any possible addition of impurities to the solution.

The solution was stored in a Pyrex glass container placed in a thermostat. A continuous flow of purified nitrogen was bubbled through the solution. Hence, dissolved oxygen was almost completely removed from the solutions. The rate of flow was determined by means of a flowmeter based on the measurement of pressure drop through tubes of different diameters. The change in pressure was read on a mercury manometer, previously calibrated. From the volumetric rate of flow $Q$, in $\mathrm{cm}^{3} / \mathrm{sec}$ we obtained the average flow velocity, $V$, in $\mathrm{cm} / \mathrm{sec}$ by

$$
V=\frac{Q}{\pi\left(r_{B}^{2}-r_{i}^{2}\right)^{2}}
$$

where $r_{e}$ and $r_{i}$ are the external and internal electrode radii. Two flowmeters were employed to cover the range of rates of flow. A diagram of the whole set-up employed is shown in Fig. 2.

\section{Properties of the solutions and experimental conditions}

The compositions of the solutions was determined by chemical analysis. The copper ion content was measured electrolytically, the sulphuric acid concentration by titrating with standard sodium hydroxide solutions. Glycerine concentration was calculated from viscosity and density measurements applying the equations recently worked out by Fenech and Tobias ${ }^{8}$ for that system.

The diffusion coefficients for copper ions in sulphuric acid solutions were taken from Gordon and Cole? $^{2}$. For the solutions containing glycerine they were calculated from the equations given by 


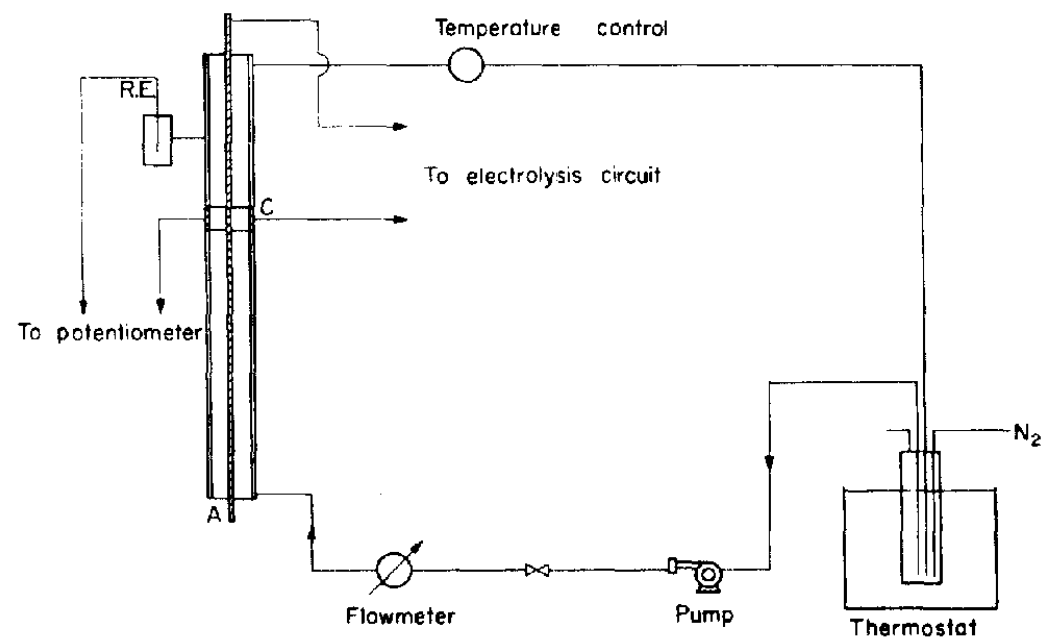

FIG. 2. Diagram of the hydrodynamic circuit.

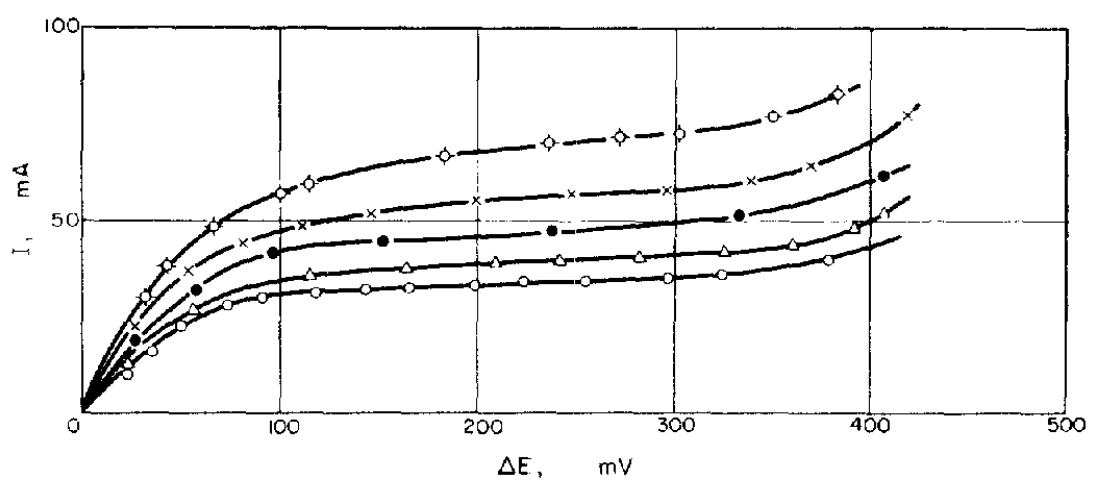

FIG. 3. Experiments at $35^{\circ} \mathrm{C}$.

$C_{0}=0.0076 \mathrm{M} ; C_{a}=1.484 \mathrm{M} ; h=6.00 \mathrm{~cm}$.

O: $9.3 \mathrm{~cm} / \mathrm{sec} ; \Delta: 11 \cdot 3 \mathrm{~cm} / \mathrm{sec} ;: 14.6 \mathrm{~cm} / \mathrm{sec}$;

$x: 17.8 \mathrm{~cm} / \mathrm{sec} ;--1-22.6 \mathrm{~cm} / \mathrm{sec}$.

Fenech and Tobias. The viscosity of the solutions, which covered the range from $1.067 \times 10^{2}$ to $7.2356 \times 10^{-2} \mathrm{~cm}^{2} / \mathrm{sec}$, was determined by a Hoeppler viscometer.

Densities were measured picnometrically.

\section{Polarization curves}

The potential of the electrode was changed from zero to a value close to $500-600 \mathrm{mV}$ by means of a potentiometric device as usually employed for electrolysis. Lead/acid batteries wcre employed as d.c. sources. The potential difference between the cathode and reference electrode was read with a Siemens-Halske potentiometer equipped with a suitable Weston galvanometcr. The current intensity was read with a Siemens precision ammeter and in a few cases- for very low intensities-it was determined by measuring the potential drop on a standard resistor in series with the cell.

Polarization curves were obtained pointwise without interrupting the electrolysis current, Once a solution at a constant temperature was flowing through the cell, polarization curves were obtained at different rates of fow one after the other, starting each time from a zero potential difference between the electrodes.

\section{RESULTS}

Polarization curves for different solutions were obtained at temperatures ranging from 25 to $45^{\circ} \mathrm{C}$ and rates of flow from 6 to $50 \mathrm{~cm} / \mathrm{sec}$. Figs. 3, 4 and 5 show some 


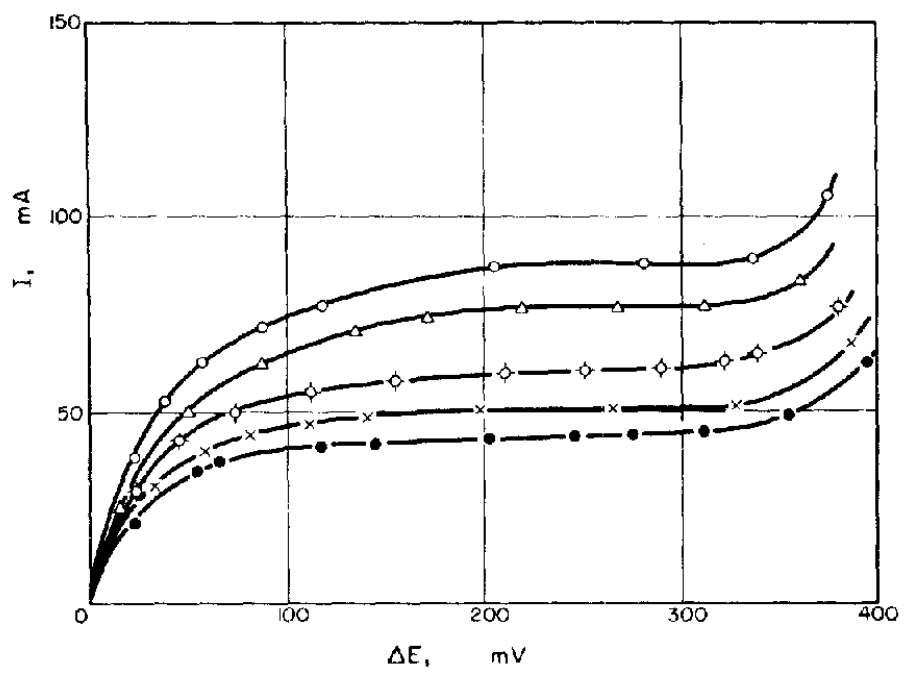

Fig. 4. Experiments at $45^{\circ} \mathrm{C}$.

$C_{0}=0.0076 \mathrm{M} ; C_{a}=1.484 \mathrm{M} ; h=6.00 \mathrm{~cm}$.

- : $8.97 \mathrm{~cm} / \mathrm{sec} ; \times: 11.5 \mathrm{~cm} / \mathrm{sec} ;-\hat{O}_{-}: 14.8 \mathrm{~cm} / \mathrm{sec}$

$\Delta: 17.6 \mathrm{~cm} / \mathrm{sec} ; 0: 20.5 \mathrm{~cm} / \mathrm{sec}$.

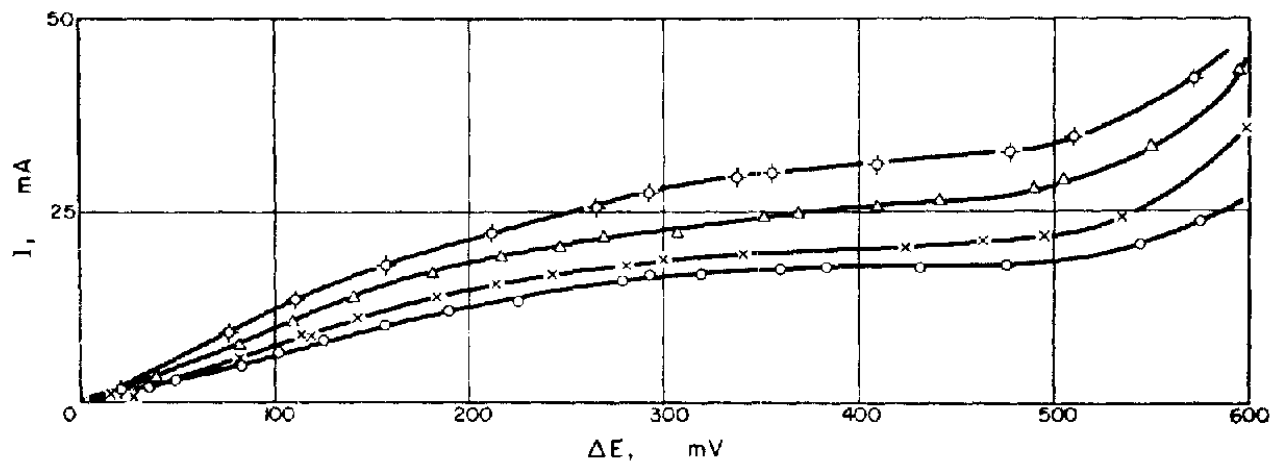

FIG. 5. Experiments with glycerine.

$C_{0}=0.0180 \mathrm{M} ; C_{a}=1.480 \mathrm{M} ; h=3.00 \mathrm{~cm}$.

$C_{p}=6.15 \mathrm{M} ; t=25^{\circ} \mathrm{C}$

O: $30.5 \mathrm{~cm} / \mathrm{sec} ; x: 40.4 \mathrm{~cm} / \mathrm{sec} ; \Delta: 52.9 \mathrm{~cm} / \mathrm{sec}$;

$-1-: 64.6 \mathrm{~cm} / \mathrm{sec}$

typical polarization curves obtained for the electrodeposition of copper under different conditions. Tables 1 to 5 present the experimental data. The following nomenclature has been used:

No. number of the experiment; $C_{0}$, molar copper ion concentration; $C_{a}$, molar sulphuric acid concentration; $C_{g}$, molar glycerine concentration; $D_{0}$, copper ion diffusion coefficient in $\mathrm{cm}^{2} / \mathrm{sec} ; \nu$, kinematic viscosity of the solution in $\mathrm{cm}^{2} / \mathrm{sec} ; V$, average velocity of flow in $\mathrm{cm} / \mathrm{sec} ; i_{L}$, limiting current density in $\mathrm{mA} / \mathrm{cm}^{2} ; \Delta C_{a}$, molar change of concentration of sulphuric acid; $k$, mass transfer constant in $\mathrm{cm} / \mathrm{sec} ; S c$, $R e$ and $S h$, respectively Schmidt, Reynolds and Sherwood numbers; $d$, diameter of the inner electrode, $h$, height of the tubular electrode (both in $\mathrm{cm}$ ); and $t$, temperature. 
TABle 1. Electrode $1 ; d=0.47 \mathrm{~cm} ; h=6.00 \mathrm{~cm} ; t=25^{\circ} \mathrm{C}$.

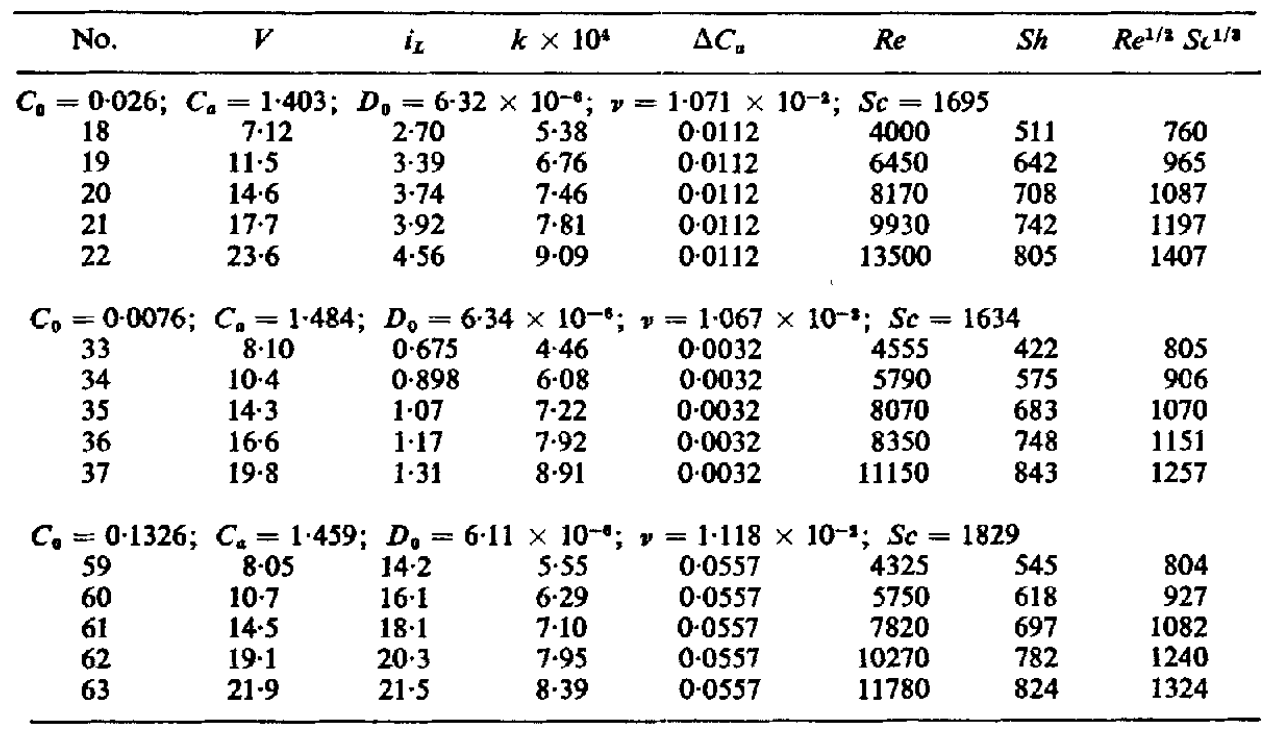

TABLe 2. Electrode $2 ; d=0.47 \mathrm{~cm} ; h=3.00 \mathrm{~cm} ; t=25^{\circ} \mathrm{C}$.

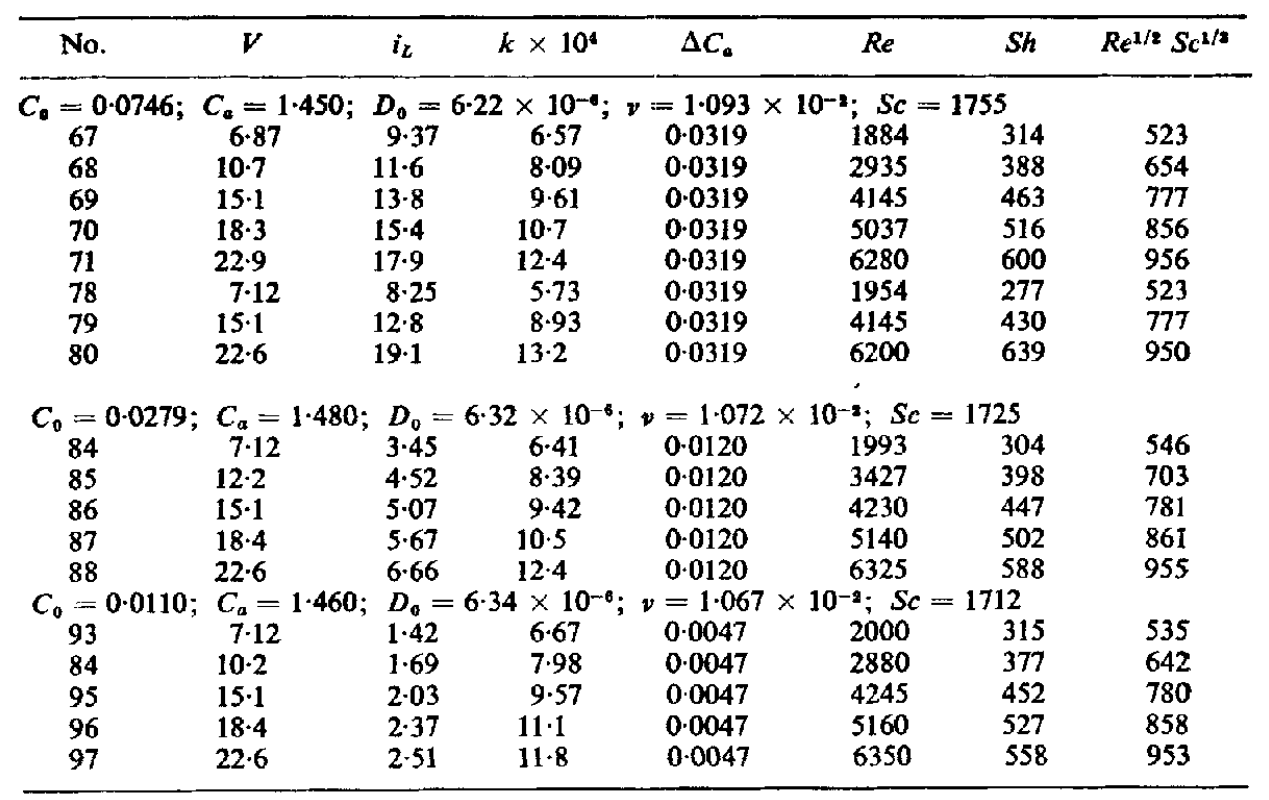

\section{INTERPRETATION}

\section{Kinetic constant and temperature}

The limiting current was obtained from polarization curves and corrected, when necessary, for the residual current. When the ionic diffusion rate is the rate-determining step in the mechanism of the electrochemical reaction, i.e. when a large excess 
Table 3. Electrode $3 ; d=0.47 \mathrm{~cm} ; h=1.50 \mathrm{~cm} ; t=25^{\circ} \mathrm{C}$.

\begin{tabular}{|c|c|c|c|c|c|c|c|}
\hline No. & $\boldsymbol{V}$ & $i_{L}$ & $k \times 10^{4}$ & $\Delta C_{a}$ & $R e$ & $S h$ & $R e^{1 / 2} S c^{1 / 2}$ \\
\hline $\begin{array}{c}C_{0}=0-1370 ; \\
119 \\
120 \\
121 \\
122 \\
123\end{array}$ & $\begin{array}{c}C_{a}= \\
7 \cdot 12 \\
11 \cdot 9 \\
15 \cdot 1 \\
18 \cdot 4 \\
22 \cdot 6\end{array}$ & $\begin{array}{r}D_{0}= \\
24 \cdot 7 \\
30 \cdot 6 \\
35 \cdot 1 \\
38 \cdot 5 \\
44 \cdot 3\end{array}$ & $\begin{array}{c}.21 \times 10^{-8} \\
9 \cdot 36 \\
11.6 \\
13 \cdot 1 \\
14 \cdot 6 \\
16.8\end{array}$ & $\begin{array}{c}\nu=1.097 \\
0.0585 \\
0.0585 \\
0.0585 \\
0.0585 \\
0.0585\end{array}$ & $\begin{array}{r}10^{-2} ; S c \\
973 \\
1625 \\
2067 \\
2510 \\
3090\end{array}$ & $\begin{array}{r}718 \\
226 \\
280 \\
317 \\
352 \\
407\end{array}$ & $\begin{array}{l}374 \\
483 \\
545 \\
600 \\
690\end{array}$ \\
\hline $\begin{array}{c}C_{0}=0: 0177 ; \\
124 \\
125 \\
126 \\
127 \\
128\end{array}$ & $\begin{array}{l}C_{a}= \\
7 \cdot 12 \\
11 \cdot 9 \\
15 \cdot 1 \\
18 \cdot 4 \\
22 \cdot 6\end{array}$ & $\begin{array}{c}D_{0} \\
2 \cdot 67 \\
3.87 \\
4.73 \\
5.28 \\
5.75\end{array}$ & $\begin{array}{c}5.33 \times 10^{-} \\
7.82 \\
11.3 \\
13.8 \\
15.5 \\
16.8\end{array}$ & $\begin{array}{l}\nu=1.06 \\
0.0076 \\
0.0076 \\
0.0076 \\
0.0076 \\
0.0076\end{array}$ & $\begin{array}{l}0^{-8} ; S \\
1000 \\
1670 \\
2122 \\
2578 \\
3172\end{array}$ & \begin{tabular}{r|}
1685 \\
185 \\
268 \\
328 \\
366 \\
398
\end{tabular} & $\begin{array}{l}376 \\
486 \\
548 \\
605 \\
671\end{array}$ \\
\hline $\begin{array}{c}C_{0}=0.0551 ; \\
129 \\
130 \\
131 \\
132 \\
133\end{array}$ & $\begin{array}{r}C_{a}= \\
7 \cdot 12 \\
11.9 \\
15 \cdot 1 \\
18 \cdot 4 \\
22 \cdot 6\end{array}$ & $\begin{array}{l}D_{0}= \\
9 \cdot 47 \\
12 \cdot 0 \\
14 \cdot 3 \\
16 \cdot 5 \\
19 \cdot 2\end{array}$ & $\begin{array}{c}.25 \times 10^{-} \\
8.91 \\
11.3 \\
13.5 \\
15.6 \\
18.0\end{array}$ & $\begin{array}{l}=1.083 \\
0.0235 \\
0.0235 \\
0.0235 \\
0.0235 \\
0.0235\end{array}$ & $\begin{array}{r}10^{-2} ; S c \\
986 \\
1648 \\
2093 \\
2542 \\
3130\end{array}$ & $\begin{array}{r}736 \\
214 \\
271 \\
323 \\
373 \\
432\end{array}$ & $\begin{array}{l}378 \\
488 \\
551 \\
607 \\
672\end{array}$ \\
\hline
\end{tabular}

Table 4. Electrode $4 ; d=0.47 \mathrm{~cm} ; h=0.75 \mathrm{~cm} ; t=25^{\circ} \mathrm{C}$.

\begin{tabular}{|c|c|c|c|c|c|c|c|}
\hline No. & $V$ & $i_{L}$ & $k \times 10^{4}$ & $\Delta C_{a}$ & $\operatorname{Re}$ & $S h$ & $R \epsilon^{1 / 2} S^{1 / 2}$ \\
\hline \multicolumn{8}{|c|}{$C_{0}=0.0436 ; C_{a}=1.450 ; D_{0}=6.27 \times 10^{-6} ; \nu=1.080 \times 10^{-2} ; S c=1725$} \\
\hline 134 & $7 \cdot 12$ & 8.90 & 10.6 & 0.0186 & 495 & 127 & 267 \\
\hline 135 & $12 \cdot 5$ & $13 \cdot 2$ & $15 \cdot 7$ & 0.0186 & 870 & 187 & 353 \\
\hline 136 & $15 \cdot 1$ & $14 \cdot 9$ & $17 \cdot 8$ & 0.0186 & 1051 & 213 & 389 \\
\hline 137 & $18 \cdot 4$ & $16 \cdot 4$ & 19.5 & 0.0186 & 1280 & 234 & 430 \\
\hline 138 & $22 \cdot 6$ & $18 \cdot 1$ & $21 \cdot 6$ & 0.0186 & 1570 & 258 & 475 \\
\hline \multicolumn{8}{|c|}{$C_{0}=0.0860 ; C_{a}=1.450 ; \quad D_{0}=6.20 \times 10^{-6} ; y=1.095 \times 10^{-2} ; S c=1767$} \\
\hline 139 & $7 \cdot 12$ & $19 \cdot 9$ & $12 \cdot 0$ & 0.0366 & 488 & 146 & 268 \\
\hline 140 & $12 \cdot 6$ & $28 \cdot 6$ & $17 \cdot 2$ & 0.0366 & 865 & 208 & 356 \\
\hline \multicolumn{8}{|c|}{$C_{\theta}=0.0222 ; C_{a}=1.420 ; D_{0}=6.32 \times 10^{-6} ; v=1.070 \times 10^{-2} ; S c=1695$} \\
\hline 144 & $7 \cdot 12$ & 4.02 & $9 \cdot 42$ & 0.0096 & 499 & 112 & 266 \\
\hline 145 & $12 \cdot 5$ & 6.45 & $15 \cdot 1$ & 0.0096 & 876 & 179 & 352 \\
\hline 146 & $15 \cdot 1$ & $7 \cdot 78$ & $18 \cdot 2$ & 0.0096 & 1060 & 216 & 388 \\
\hline 147 & $18 \cdot 4$ & $8 \cdot 20$ & $19 \cdot 2$ & 0.0096 & 1290 & 228 & 428 \\
\hline 148 & $22 \cdot 6$ & $9 \cdot 56$ & $22 \cdot 4$ & 0.0096 & 1585 & 266 & 475 \\
\hline
\end{tabular}

Table 5. Electrode $2 ; d=0.47 \mathrm{~cm} ; h=3.00 \mathrm{~cm} ; t=25^{\circ} \mathrm{C}$.

\begin{tabular}{|c|c|c|c|c|c|c|c|}
\hline No. & $V$ & $i_{L}$ & $k \times 10^{4}$ & $\Delta C_{a}$ & $R e$ & $S h$ & $R e^{1 / 2} S C^{1 / 2}$ \\
\hline $\begin{array}{c}C_{\mathrm{0}}=0.0183 \\
149 \\
150 \\
151 \\
152\end{array}$ & $\begin{array}{l}C_{a}=1.460 \\
33.3 \\
52.6 \\
45.9 \\
60.0\end{array}$ & $\begin{array}{l}C_{g}= \\
2 \cdot 28 \\
2 \cdot 82 \\
2 \cdot 66 \\
3 \cdot 25\end{array}$ & $\begin{array}{r}84 ; D_{0} \\
6 \cdot 46 \\
7.98 \\
7.53 \\
9 \cdot 20\end{array}$ & $\begin{array}{r}21 \times 10^{-} \\
0.0050 \\
0.0050 \\
0.0050 \\
0.0050\end{array}$ & $\begin{aligned} v= & 2 \cdot 5467 \\
& 2260 \\
& 3490 \\
& 2875 \\
& 4370\end{aligned}$ & $\begin{array}{r}7 \times 10^{-2} ; \\
604 \\
746 \\
705 \\
860\end{array}$ & $\begin{array}{r}S c=7940 \\
950 \\
1180 \\
1070 \\
1320\end{array}$ \\
\hline $\begin{array}{l}C_{0}=0.0180 \\
153 \\
154 \\
155 \\
156\end{array}$ & $\begin{array}{l}C_{\mathrm{a}}=1 \cdot 480 \\
30 \cdot 5 \\
40 \cdot 4 \\
52 \cdot 9 \\
64 \cdot 6\end{array}$ & $\begin{array}{l}C_{o}= \\
1.10 \\
1.28 \\
1.59 \\
1.95\end{array}$ & $\begin{array}{r}15 ; D_{0}= \\
3 \cdot 15 \\
3 \cdot 69 \\
4 \cdot 58 \\
5 \cdot 62\end{array}$ & $\begin{array}{c}.26 \times 10^{-} \\
0.0026 \\
0.0026 \\
0.0026 \\
0.0026\end{array}$ & 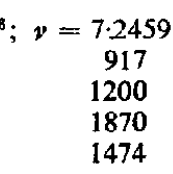 & $\begin{array}{r}\times 10^{-2}: \\
751 \\
878 \\
1090 \\
1340\end{array}$ & $\begin{aligned} & S c= 57500 \\
& 1170 \\
& 1340 \\
& 1670 \\
& 2000\end{aligned}$ \\
\hline
\end{tabular}


of an inert electrolyte is present, the limiting current, $I_{L}$, is related to the concentration of the ionic species reacting on the electrode by

$$
I_{L}=k \cdot A \cdot C_{0} \cdot z \cdot F \text {, }
$$

where $k$ is the formal average kinetic constant for the whole area $A$ of the electrode and $C_{0}$ is the bulk concentration of the reacting diffusing species; $z$ and $F$ have their usual significance. Equation (2) was employed to calculate the constant $k$.

The temperature dependence of $k$, as in other case ${ }^{10}$, can be also represented in the present case by an Arrhenius equation. From a plot of $\log k$ vs. $1 / T$, where $T$ is temperature in ${ }^{\circ} \mathrm{K}$, a heat of activation of $3850 \pm 200 \mathrm{cal} / \mathrm{mol}$ is obtained.

This figure was employed to calculate the limiting current density and the kinetic constant at $25^{\circ} \mathrm{C}$ when the constant temperature of the run differed from this temperature. Therefore, the following calculations have been referred to that temperature. Values of $k$ corrected to $25^{\circ} \mathrm{C}$ are included in the tables.

\section{The application of dimensional analysis}

As shown elsewhere ${ }^{11}$ and especially remarked by $\mathrm{Ibl}^{12}$, dimensional analysis is a useful tool to relate the experimental variables of a diffusion-convection controlled electrochemical process.

The dimensional groups of interest for this case are

$$
\begin{gathered}
\text { Sherwood number: } S h-\frac{k \cdot X}{D_{0}}, \\
\text { Reynolds number: } R e=\frac{V \cdot X}{v}, \\
\text { Schmidt number: } S c=\frac{v}{D_{0}},
\end{gathered}
$$

where $X$ is a characteristic length in $\mathrm{cm}$.

The Sherwood number involves the mass-transfer kinetic constant and it can be taken as a ratio between the characteristic length and the thickness of the effective diffusion layer.

The Reynolds number relates driving forces acting on the liquid and viscous forces which tend to slow down the stream.

The Schmidt number relates the physico-chemical properties which determine momentum transfer by viscous effect due to velocity gradients and mass transfer by diffusion due to concentration gradients.

Sherwood and Reynolds numbers were defined in terms of electrode height, $h$, for reasons which will be referred to later.

For the present case a relationship of the form

$$
S h=K \cdot R e^{\cdot c} \cdot S c^{y}
$$

has to be established. The parameters $K, x$ and $y$ were calculated from the experimental data.

3. The kinetic tonstant and the rate of flow of the solutions

The formal average kinetic constant, calculated from equation (2), has been plotted as a iunction of the square root of the average flow velocity. Fig. 6 shows the 


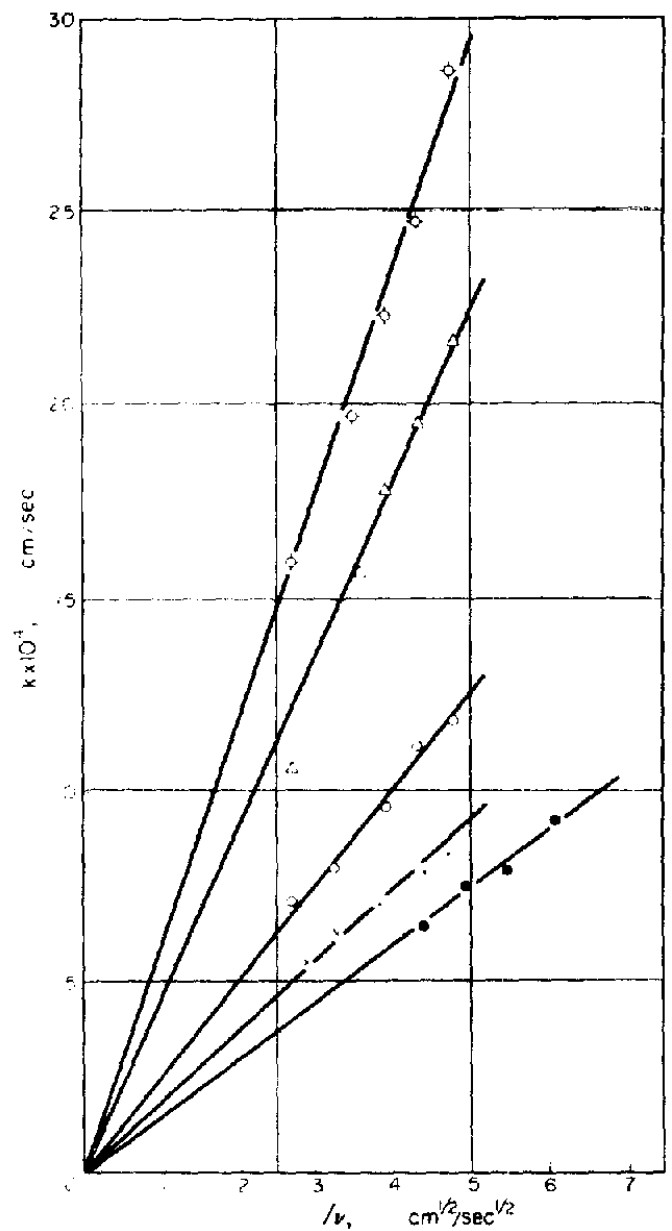

Fig. 6. Plot of $k$ vs. $V^{1 / 2}$.

O: exp. 93 to $97 ;-$ : exp. 149 to $152 ; \times: \exp .59$ to 63

$\Delta: \exp 134$ to $138 ;-$ Cl- $^{-}$exp. 119 to 123.

linear relationship obtained; it suggests very reasonably that exponent $x$ in equation (3) is $1 / 2$.

\section{The kinetic constant and the ratio involved in Schmidt number}

It was important to find the relationship between the rate constant and Schmidt number, which was obtained with a tubular electrode of fixed dimensions, changing only the physical properties of the electrolytic solution. Copper sulphate-sulphuric acid solutions containing glycerol were employed to find the relationship. In these experiments the Schmidt ratio was varied between $1 \times 10^{3}$ and $50 \times 10^{3}$. A log-log plot of Sherwood vs. Schmidt numbers for constant Reynolds number is shown in Fig. 7. Straight lines of slope $1 / 3$ have been drawn through the points and this number corresponds to the value of $y$ in equation (3). 


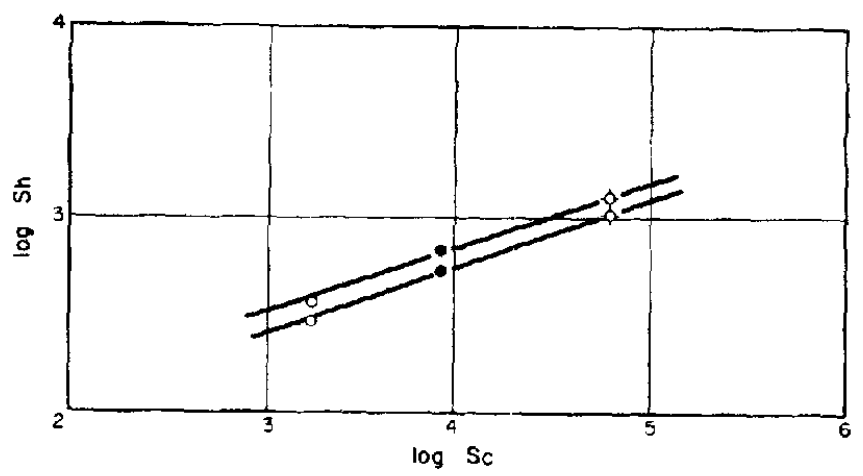

Fig. 7. Log-log plot of Sh vs. Sc numbers.

$0: C_{q}=0 ; \bullet: C_{g}=2.84 \mathrm{M} ;-\dot{0}: C_{q}=6.15 \mathrm{M}$.

\section{The correlation for the ionic mass-transfer process in the tubular cell}

Finally, to work out the general equation comprising all the variables involved in the process a further analysis is necessary, in which the average properties of the system have to be considered.

The final calculations of the dimensionless numbers would have to be done employing the average properties of the solutions taking into account the fact that its concentration is not uniform when we are approaching the working electrode surface.

In the present case, when a steady electric current flows through the cell, the current is transported mainly by the inert electrolyte added to the solution. This inert electrolyte is carried to the electrode without discharging on it; hence its concentration increases on the electrode surface. Once a steady state is reached, the amount of inert electrolyte brought by migration is compensated by an equal amount which leaves the electrode by convection and diffusion. The steady state on the electrode surface may be expressed by

$$
i_{L} \cdot t_{a}=k_{a} \cdot z . F . \Delta C_{a} .
$$

This increment of concentration of the inert electrolyte, $\Delta C_{a}$, on the electrode surface has to be considered in the evaluation of the average kinetamatic viscosity and diffusion coefficient. The equation which allows the calculation of $\Delta C_{a}$ by successive approximations is ${ }^{14}$

$$
\Delta C_{a}=t_{a}\left(\frac{D_{0}}{D_{a}}\right)^{3} C_{0}
$$

where $t_{a}$ is the transport number of the hydrogen ion and $D_{a}$ its diffusion coefficient. For sulphuric acid solutions, $D_{a}$ and $t_{a}$ have been taken from the literature. ${ }^{13}$ As is indicated in the tables the $\Delta C_{a}$ values in our experiments were small. Therefore, considering the experimental error involved in the determinations, the final values of Sherwood, Schmidt and Reynolds numbers were calculated without taking into account the average properties, but the bulk ones.

The general correlation worked out, from a least square calculation, for Sherwood, Schmidt and Reynolds numbers may be written:

$$
S h=0.647 \cdot R e^{1 / 2} \cdot S c^{1 / 3}
$$

A plot of $S h v s . R e^{1 / 2} . S c^{1 / 3}$ is shown in Fig. 8. 


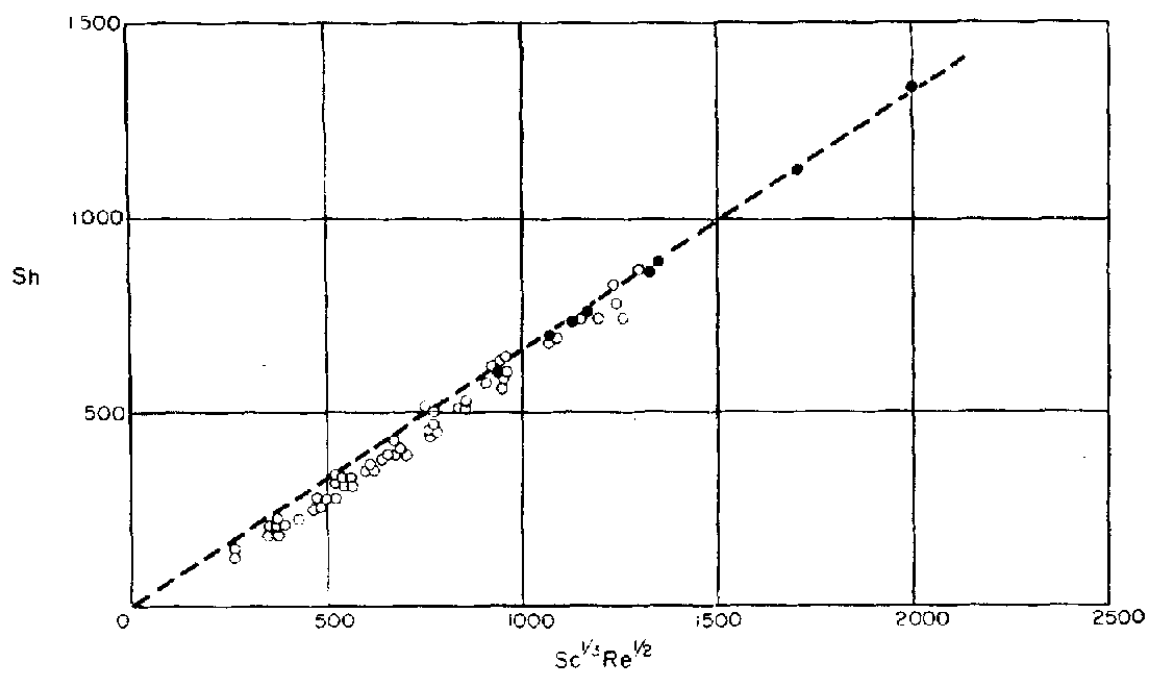

Fig. 8. Plot of $S h$ vs. $S c^{1 / 3}$. $R e^{1 / 2}$. Dotted line was drawn with eq. (20).

The maximum experimental error involved in the equation (6) is 14 per cent, distributed as follows: Sherwood number, 9.5 per cent; Reynolds number, 3.5 per cent; Schmidt number, 1.7 per cent. The error in the limiting current is less than 4 per cent and that of the velocity of flow is estimated as 7 per cent.

6. The expressions for the limiting current density, the kinetic constant and the thickness of the Nernst diffusion laver

From equation (6) the following expressions are obtained:

$$
\begin{aligned}
i_{L} & =0 \cdot 647 \cdot h^{-1 / 2} \cdot V^{1 / 2} \cdot D_{0}^{2 / 3} \cdot v^{-1 / 6}, \\
k & =0 \cdot 647 \cdot z \cdot F \cdot C_{0} \cdot h^{-1 / 2} \cdot V^{1 / 2} \cdot D_{0}^{2 / 3} \cdot v^{-1 / 6}, \\
\delta_{N} & =1 \cdot 56 \cdot h^{1 / 2} \cdot V^{-1 / 2} \cdot D^{1 / 3} \cdot y^{1 / 6} .
\end{aligned}
$$

The dependence of $\delta_{N}$ with the electrode height is presented in Fig. 9.

\section{DISCUSSION}

The interesting feature of the present work is represented by equation (6), which expresses the rate of ionic mass transfer in the annular electrode of the tubular cell. An analogous equation has been derived recently by Wranglén ${ }^{6,14}$ for a horizontal plate electrode along which the solution is flowing in a direction parallel to its surface, while the mass-transfer direction is normal to that surface. Wranglén has worked out the kinetic equation for ionic mass transfer by applying Eckert's ${ }^{15,16}$ solution for the heat-transfer problem at a horizontal plate based on von Karmán's approximation.

This approach of the mass transfer problem can undoubtedly be extended to a vertical tubular electrode if the following assumptions are fulfilled: (a) the radius of curvature of the electrode is much larger than the effective diffusion layer thickness at the working electrode; (b) the mass transfer due to natural convection is negligible as compared to that by forced convection. Over the tubular electrode surface, two 
processes occur simultaneously: mass transfer, in this case the rate-determining step of the electrochemical reaction, and momentum transfer which results as a consequence of viscous forces. If the above assumptions are made the general equation for mass transfer can be written as usual in orthogonal coordinates:

$$
\frac{\mathrm{d}}{\mathrm{d} x} \int_{0}^{L}\left(C_{0}-C_{\mathrm{e}}\right) \cdot u \cdot \mathrm{d} y=D\left(\frac{\mathrm{d} C}{\mathrm{~d} y}\right)_{y=0},
$$

where $x$ is the flow direction and corresponds to heights measured on the electrode, $y$ the mass-transfer direction, normal to $x, C_{0}$ the bulk concentration of the diffusing species, $C_{e}$ its concentration on the electrode surface, $u$ the local fluid velocity, and $L$ the thickness of the layer within which diffusion takes place. The limits of the integral actually extend from zero to $\delta_{d}$, the thickness of the diffusion boundary layer. It is assumed that no transport occurs in the $z$ direction. The right hand side term of equation (10) expresses the rate of mass transfer per unit electrode area.

Similarly, the general equation for momentum transfer is

$$
\frac{\mathrm{d}}{\mathrm{d} x} \int_{0}^{L^{\prime}} u\left(u_{s}-u\right) \mathrm{d} y=v\left(\frac{\mathrm{d} u}{\mathrm{~d} y}\right)_{y=0},
$$

where $u_{s}$ is the flow velocity in the bulk of the solution and $L^{\prime}$ refers to the distance from the electrode surface in the $y$ direction, where there is a velocity gradient. As before, the integration of equation (11) is from zero to $\delta_{h}$, the thickness of the hydrodynamical boundary layer.

The integration of equation (10) and (11) assuming cubic parabolic velocity and concentration profiles and that both the hydrodynamical and diffusion boundary layer originates at the same point of the surface, yields an equation which expressed in terms of dimensionless numbers and local properties of the solution, can be written

$$
S h_{x}=0.331 R e_{x}^{1 / 2} \cdot S c^{1 / 3} \text {. }
$$

When equation (12) is extended to the whole electrode area it becomes

$$
S h_{h}=0.662 R e_{h}^{1 / 2} \cdot S c^{1 / 3} .
$$

The general solution for the case in which the hydrodynamical boundary layer is not formed simultaneously with the diffusion boundary layer, is

$$
S h_{x}=0 \cdot 331 . R e_{x}{ }^{1 / 2} S c^{1 / 3}\left[1-\left(\frac{x_{0}}{x}\right)^{3 / 4}\right]^{-1 / 3}
$$

Equation (14) has recently been considered by Wranglen and Nilsson ${ }^{6}$ for the flat plate electrode. This equation reduces to equation (13) if $x_{0}=0$, where $x_{0}$ is the distance from the point of the surface where the hydrodynamical boundary layer originates to the point where the diffusion boundary layer begins to form.

Both equations (13) and (14) predict linear relationship between the mass-transfer kinetic constant and the square root of velocity of the solution ; $k$ is inversely proportional to the square root of the electrode height, and directly proportional to the cube root of the ratio between kinematic viscosity and diffusion coefficient. Equation (13) is compared to the experimental data in Fig. 8.

That equation also allows the calculation of the effective thickness of the diffusion 
boundary layer on the electrode. This has been done and compared to the experimental results in Fig. 9, where $\delta_{N}$. means the thickness of the Nernst diffusion layer assuming a linear concentration profile.

Our results indicate that the cylindrical surfaces of the electrode can be regarded as a plane to a first approximation.

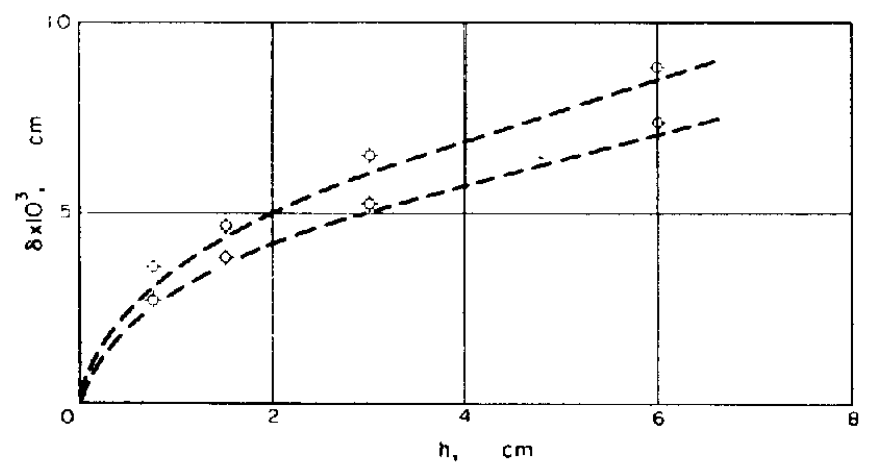

Fig. 9. The Nernst average diffusion layer plotted vs. electrode heights. Full line has been drawn with eq. (9).

$$
-1 \mathrm{~V}=21.6 \mathrm{~cm} / \mathrm{sec} ; \mathrm{O}: \mathrm{V}=15.1 \mathrm{~cm} / \mathrm{sec}
$$

Nevertheless the actual situation in the cell we have studied is more complicated because the hydrodynamical boundary layers formed in the inner and outer walls of the tube become very thick, yielding even ahead of the leading edge of the working electrode, something like the well known Pouseuille parabolic velocity distribution observed in pipes after a certain distance from the entrance. Schlichting ${ }^{17}$ has derived for parallel solid walls the following equation to calculate the distance $d$, at which the two hydrodynamic boundary layer merge:

$$
d=0 \cdot 04 . a \cdot R e,
$$

where $a$ is the distance between the walls and $R e$ is the Reynolds number referred to the width of the channel.

Schlichting's equation was derived for two parallel solid walls in which the liquid inflow is parallel to the surface of the walls. The behaviour of our cylindrical surfaces can be regarded as that of plane surfaces and although in the present case the liquid enters the cell perpendicularly to the axis of the cylindrical tube, at least a rough approximation of $d$ can be obtained with equation (15). In the present case $a$ is about $0.6 \mathrm{~cm}$; we thus obtain for $V=20 \mathrm{~cm} / \mathrm{sec}, \nu=10^{-2} \mathrm{~cm} / \mathrm{sec}$, and $R e=1200$, a value $d=29 \mathrm{~cm}$. This value is about the same as the length of the inert interface used in our experiments, $22 \mathrm{~cm}$. Therefore it is reasonable to assume that in this case the two hydrodynamical boundary layers have merged or have almost merged when the leading edge of the electrode is reached. This merging may explain why satisfactory agreement is obtained between experimental and calculated values without taking the inlet length into consideration (the first factor reduces $\delta$, the second increases it).

Acknowledgements-The authors thank the Director of the Institute, Dr. H. J. Schumacher for his interest in this work and to Dr. N. Ibl for his interesting comments and suggestions. J. C. B. thanks the Facultad de Ciencias Físicomatemáticas for a Fellowship. 


\section{REFERENCES}

1. B. Levich, Disc. Faraday Soc. 1, 37 (1947).

2. A. Rius, J. Llopis and S. Polo, Anales Fis. y Quim. 45, 1039 (1949).

3. P. Delahay, New Instrumental Methods in Electrochemistry. Interscience, New York (1954). P. LÉvêque, J. Chim. Phys. 49, 266 (1952).

4. C. S. Lin, E. B. Denton, H. S. Gaskill and G. L. Putman, Ind. Eng. Chem. 43, 2136 (1951).

5. J. Jordan and R. A. JAvick, J. Amer. Chem. Soc. 80, 1264 (1958).

6. G. Wranglén and O. Nilsson, Electrochim. Acta 7, 111 (1962).

7. J. JORDAN and R. A. JAVICK, Electrochim. Acta 6, 23 (1962).

8. E. J. Fenech and C. W. Tonias, Electrochim. Acta 2, 311 (1960).

9. A. R. Gordon and A. Cole, J. Phys. Chem. 40, 733 (1936).

10. A. J. Arvía and J. W. Carrozza Electrochim. Acła 7, 65 (1962).

11. L. L. Bircumshaiw and A. C. RidDiford, Quart. Revs. (London) 6, 157 (1952).

12. N. IBL, Electrochim. Acta 1, 117 (1959).

13. H. S. HARNED and B. B. OWEN, The Physical Chemistry of Electrolytic Solutions, 2nd Ed. Reinhold, New York (1950).

14. G. Wranglén, Acta Chem. Scand. 13, 830 (1959).

15. E. R. G. Eckert and R. M. DRAKe JR., Heat and Mass Transfer 2nd. Edition. McGraw-Hill, New York (1959).

16. E. Pohlausen, Z. angew. Math. Mech. 1, 115 (1921).

17. H. Schlichting, Boundary Layer Theory, p. 170. McGraw-Hill. New York (1960). 